\title{
Zooming into the genomic vicinity of the major locus for vicine and convicine in faba bean (Vicia faba L.)
}

\author{
Rebecca Tacke ${ }^{1}$, Wolfgang Ecke ${ }^{1}$, Michael Höfer ${ }^{2}$, Olaf Sass ${ }^{3}$, \\ Wolfgang Link ${ }^{1}$ (wlink@gwdg.de) \\ ${ }^{1}$ Georg-August-Universität Göttingen, DNPW, Carl-Sprengel 1, Germany \\ ${ }^{2}$ RLP AgroScience GmbH, Breitenweg 71, 67435 Neustadt a.d. Weinstrasse, Germany \\ ${ }^{3}$ Norddeutsche Pflanzenzucht Hans-Georg Lembke KG, 4363 Holtsee, Germany
}

\section{Abstract}

The versatility of faba bean (Vicia faba L.) seed as valuable protein feed is hampered by its relatively high level of the compounds vicine and convicine (VC), which are antinutritive factors in poultry and further non-ruminant feed. The objective here was to develop the first-ever genetically low-VC winter faba bean. Hence, the low VC allele vc-, that should be the basis of a known, major locus for VC, need verification and molecular identification and be based on appropriately developed DNAmarkers; the low VC feature awaited its transfer into the high-performing winter faba bean germplams. Based on bi-parental $\mathrm{F}_{2}$-families and isogenic lines, we thus developed highly useful SNP markers exploiting transcriptomic data. Furthermore, we fine-mapped and, based on synteny to Medicago truncatula and Cicer arietinum, we identified a candidate gene for the VC locus. A novel, genetically low VC winter faba bean population was bred. The path is now well-prepared for further marker-based breeding progress.

\section{Introduction}

Faba bean (Vicia faba L.; V.f.) is a large-seeded, annual grain legume which is grown for food and feed. It is appreciated for its high protein content of approximately 30\% (Crépon et al. 2010; Link et al. 1994), as a regional vegetal protein source and as an alternative crop to improve soil fertility and break rotation circles of pests and diseases (Köpke and Nemecek 2010; Kulak et al. 2013). Genomic tools are still underdeveloped for faba bean (Annicchiarico et al. 2017); a sequence of the huge genome of faba bean (13 Gb) is not yet available. Therefore, the high syntenic correspondence of Vicia faba to the sequenced genomes of Medicago truncatula (M.t.), Cicer arietinum (C.a.) and further legumes of the subfamily Faboideaei is of high importance for genomic analyses. Faba beans are cultivated in Germany on only approximately 50.000 ha (Statistisches Bundesamt 2020). One limiting factor is the presence of the antinutritive seed compounds vicine and convicine (VC), two pyrimidine glycosides which occur in faba bean seed with approx. $0.3 \%$ up to $1.5 \%$ in dry matter. This quantita- 
bioRxiv preprint doi: https://doi.org/10.1101/2021.02.19.431996; this version posted February 20, 2021. The copyright holder for this preprint (which was not certified by peer review) is the author/funder, who has granted bioRxiv a license to display the preprint in perpetuity. It is made available under aCC-BY-NC 4.0 International license.

tive variation has a clear genetic component (Duc 1997; Frauen et al. 1984; Khamassi et al. 2013). Vicine and convicine occur in an approximate 2:1 ratio in faba bean seeds (Goyoaga et al. 2008). Faba beans contain VC in all parts of the plant (Goyoaga et al. 2008). These compounds are nearly unique to the genus Vicia; Momordica charantia (M.c.) is the only species outside this genus containing vicine (Gauttam and Kalia 2013; Khazaei et al. 2019).

More than 400 million people will, upon ingestion of vicine and convicine, suffer from a hemolytic anemia, called favism, caused by a human X-chromosomal inherited genetic deficiency of glucose-6phosphate-dehygrogenase (G6PD). This human genetic condition has a delicate epidemiological connection to malaria (Arese 2006; Arese et al. 2012; Luzzatto and Arese 2018).

Vicine and convicine can also have a negative effect e.g. on laying hen and broiler performances (Guillaume and Bellec 1977; Halle 2006; Larbier and Leclercq, 1994; Marquardt et al. 1981; Munduuli et al. 1981; Muduuli et al. 1982; Naber et al. 1988; Olaboro et al. 1981a; Olaboro et al. 1981b).

Duc et al. (1989) reported the presumably monogenetically inherited low vicine and convicine (LVC) content of the genebank accession 1268(4)(1) from Radzikov (Poland), which has since been used in breeding and research. This accession showed a seed content of $0,046 \%$ of $V C$, this is about $1 / 10$ to $1 / 20$ of the wild type seed content. That trait is controlled by one locus, designated as VC locus, with alleles VC+(wild type) and vc- (from that genebank accession 1268(4)(1)). The low VC level in homozygous vc-/vc- faba bean genotypes prevents favism in G6PD-deficient humans (Gallo et al. 2018) and prevents dietary disadvantages if such faba beans are used as compounds of feed (Crépon et al. 2010). Heterozygosity at the VC locus causes approximately intermediate VC values.

Based on scattered hints in classical literature, vicine and convicine are assumed to be formed in the faba bean seed coat and transported into the embryo (Duc et al. 1989; Brown and Roberts 1972).

The biosynthetic pathway to vicine and convicine was unknown until recently, when Björnsdotter et al. (bioRxiv preprint, 2020) presented new, pioneering findings, which provided convincing experimental evidence that a bi-functional RIBA1 protein, which catalyzes the first step of the riboflavin biosynthetic pathway, also catalyzes the key step of the so far unresolved vicine and convicine pathway. Starting with the GTP cyclohydrolase II function of this protein, the two pyrimidine glucosides are synthesized from GTP as demonstrated by feeding isotopically labelled GTP precursor into roots of $V$. faba. However, the additional enzymatic steps, which finally lead to the compounds vicine and convicine, remain to be elucidated, although the authors propose that VC are synthesized in three additional steps from the first two intermediates in the riboflavin pathway, respectively, the first of which is probably catalyzed by an N-glycosidase described by Frelin et al. (2015). Björnsdotter et al. (2020) could also show that there is a copy of the gene encoding the RIBA1 protein at the VC locus, 
bioRxiv preprint doi: https://doi.org/10.1101/2021.02.19.431996; this version posted February 20, 2021. The copyright holder for this preprint (which was not certified by peer review) is the author/funder, who has granted bioRxiv a license to display the preprint in perpetuity. It is made available under aCC-BY-NC 4.0 International license.

whose GTP cyclohydrolase II function is destroyed by a frameshift mutation in the vc- allele. This gene was consequently named VC1.

A major objective of research of VC characteristics is to facilitate breeding of faba beans which are genetically low in vicine and convicine seed content. The black and white hilum colours of faba bean seeds, a monogenic trait (Sirks 1931), can be used as morphological marker to select for LVC status. The accession 1268(4)(1), source of the LVC feature, shows white seed hilum. The linkage between the VC locus and the hilum colour locus is relatively tight (5-10cM; Duc et al. 2004; Khazaei et al. 2017). Yet, white versus black hilum is only visible late in the life of plants, when their seeds are mature. In an early attempt to overcome this limitation, Gutierrez et al. (2006) developed two CAPS markers by bulked segregant analysis, which were linked to the VC locus. Later, Khazaei et al. (2015) were able to map the VC locus as a major QTL on the large first chromosome of faba bean. The QTL mapped in an interval of $3.6 \mathrm{cM}$, flanked by two pairs of cosegregating SNP markers. Unfortunately, the two markers closest to this mapped QTL $(0.8 \mathrm{cM})$ proved to be not diagnostic for the trait in a larger set of diverse genotypes.

The genetic map used for the mapping of the VC locus had been constructed with SNP markers (Khazaei et al. 2014) that were a subset of a larger set of 687 SNP markers which were used to construct a comprehensive consensus map for faba bean (Webb et al. 2016). The majority of these SNP markers had been developed based on selected mRNAseq contigs of faba bean that could be unambiguously assigned to a specific gene of M.t. by sequence comparisons. These markers therefore allow comparative mapping between faba bean and $M$. truncatula. Khazaei et al. (2015) used this approach to identify a region on chromosome 2 of $M$. $t$. with strong collinearity to the region in faba bean carrying the VC locus. A total of 340 genes were found in $M . t$. in the interval delimited by the markers flanking the VC locus. However, due to lacking knowledge about the biosynthetic pathway for vicine and convicine, it was not possible to identifiy a candidate gene for the VC locus. In an early approach to identify candiate genes for the VC locus, Ray et al. (2015) identified six RNAseq contigs that were differentially expressed between high and low VC genotypes. One of these contigs, contig 4518, was later located by Khazaei et al. (2017) in M. $t$. in the target region for the VC gene on chromosome 2 . The contig 4518 corresponds to the $M$. $t$. gene Medtr2g009270, which is annotated as 3,4-dihydroxy-2-butanone 4-phosphate synthase. In soybean and chickpea, the same gene is annotated as RIBA 1, a bifunctional riboflavin biosynthesis protein (Khazaei et al. 2017) that has two catalytic domains, one with a 3,4-dihydroxy-2-butanone 4phosphate synthase activity and a second one with a GTP cyclohydrolase activity. Based on contig 4518, Khazaei et al. (2017) developed an SNP marker whose segregation completely matched the segregation of VC content in a RIL population from a cross between a high and low VC genotype and 
in a set of 51 diverse genotypes. A comprehensive and detailed review on the current classical and molecular genetic background of the VC feature of faba bean was very recently presented by Khazaei et al. (2019).

Here, the main objectives were to demonstrate and facilitate the breeding of faba beans with low VC content. Therefore, we developed new SNP markers which were closely linked to the VC locus via fine-mapping and, if possible, locate and identify the VC gene.

Finally, we aimed to employ all our findings to develop a novel, LVC winter faba bean germplam.

\section{Material and Methods}

\section{Plant material for genetic analyses}

We used two pairs of near-isogenic lines (NILs) for mRNA analysis and as crossing parents to develop two $F_{2}$ mapping populations (Cross1, Cross2). These two NIL pairs were themselves generated from two crosses of a high vicine and convicine (HVC) and a LVC parental inbred line, respectively. The first NIL pair originated from the cross between the inbred line Mélodie/2 and ILB938/2. Mélodie/2 was bred via single-seed descent (SSD) from the French LVC cultivar Mélodie, whereas ILB938/2 was bred via SSD from the HVC gene bank accession ILB938 (Khamassi et al. 2013; Khazaei et al. 2015). The second NIL pair was accordingly generated from a cross facilitated by NPZ (Norddeutsche Pflanzenzucht Hans-Georg Lembke KG). This cross included the cultivar Fabelle as the LVC parent. From both crosses, recombinant inbred lines (RILs) were bred until generation F5 (Khazaei et al. 2015). Here, one rare F5-individual per cross was identified which gave F6 offspring that still segregated for VC and included a homozygous HVC and homozygous LVC individual. These individuals were maintained by self-fertilization and became one pair of NILs. Hence, one such pair of NILs was derived from each of the two initial crosses. From Mendelian expectation, the two lines of each NIL pair should be isogenic at about $15 / 16$ of their genome.

These were the near-isogenic parents for Cross 1:

- "Mél/2*ILB938/2-139-1 (LVC)"

- “Mél/2*ILB938/2-139-2 (HVC)"

These were the near-isogenic parents for Cross 2:

- “NPZ-848-3 (LVC)”

- "NPZ-848-4 (HVC)"

\section{Creation of mapping populations}

To create the two F2- mapping populations, the $F_{1}$ of Cross 1 and of Cross 2 were self-fertilized under insect-proof conditions. These two mapping populations contained $\mathrm{N}=751$ (Cross 1 ) and $\mathrm{N}=899$ (Cross 2) $F_{2}$ - individuals. The two $F_{2}$ populations where subsequently used to generate linkage map frag- 
bioRxiv preprint doi: https://doi.org/10.1101/2021.02 19.431996; this version posted February 20, 2021. The copyright holder for this preprint (which was not certified by peer review) is the author/funder, who has granted bioRxiv a license to display the preprint in perpetuity. It is made available under aCC-BY-NC 4.0 International license.

$\underline{\text { ments }}$ and to conduct fine-mapping analyses while seed coat material from their parental NIL pairs was further used for mRNA analyses.

\section{Plant material for breeding novel, winterhardy, LVC faba bean lines}

This breeding program started in 2006 by crossing Hiverna/2 and Mélodie/2. Hiverna/2 had been bred via SSD from Hiverna, an old, very winterhardy German winter faba bean cultivar with HVC phenotype (Bundessortenamt 2019).

Until 2015 and generation $\mathrm{BC}_{2} \mathrm{~F}_{2}$, the selection was carried out via hilum colour among $\mathrm{F}_{2}, \mathrm{BC}_{1} \mathrm{~F}_{2}$ and $B C_{2} F_{2}$ individuals. For actual backcrossing, corresponding $F_{3}, B C_{1} F_{3}$ and $B C_{2} F_{3}$ individuals were used. Starting in $\mathrm{BC}_{3} \mathrm{~F}_{2}$, selection was based on high liquid pressure chromatography (HPLC) analyses (service provided by National Institute of Agricultural Botany in England, NIAB 2021). Further on, we employed marker assisted selection for the next backcrossing program.

\section{mRNA sampling, RNA-Isolation, transcriptome, and SNP analysis}

For mRNA analyses, we collected seed coats of immature seeds (Figure 1), in their developmental stages four, five and six (Borisjuk et al. 1995).
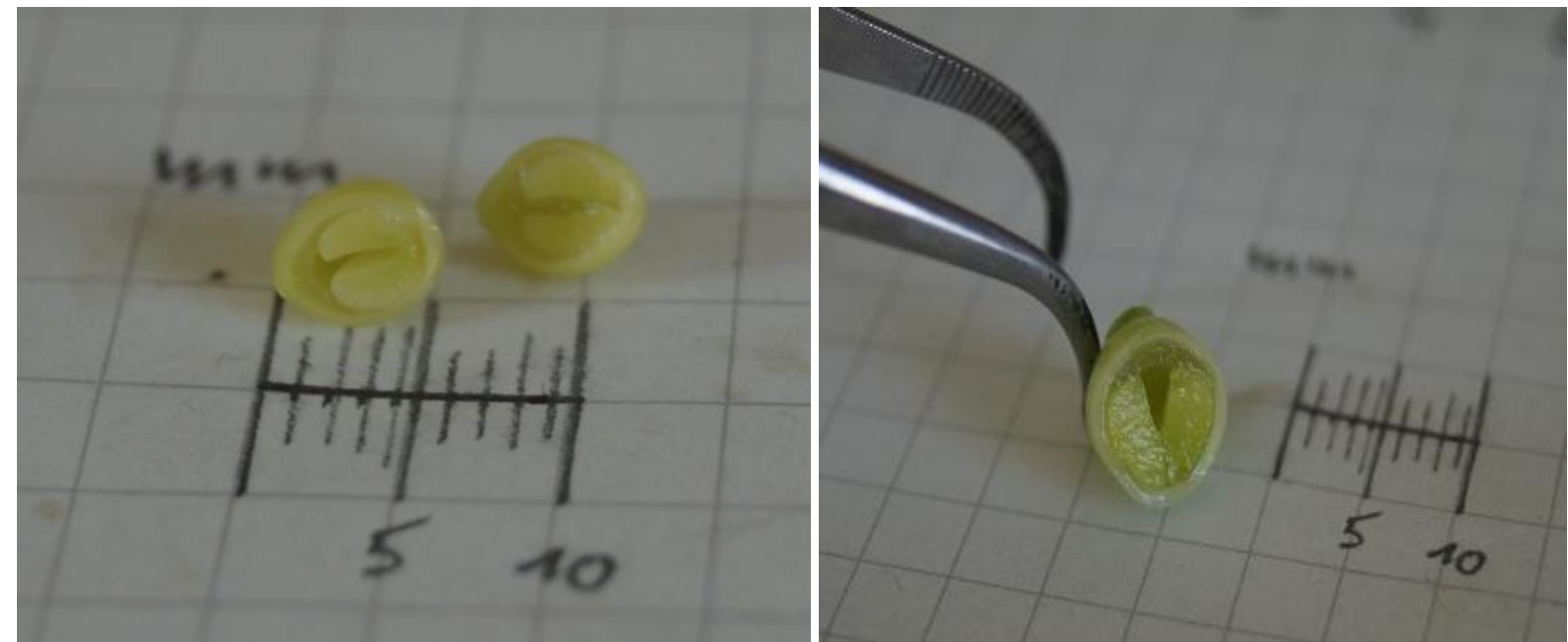

Figure 1. Cross-section of a Vicia faba seed in developmental stage 4 (left) and stage 5 (right).

The frozen tissue was ground to a fine powder under liquid nitrogen conditions using a mixer mill (MM200, Retsch, Haan, settings $30 \mathrm{~Hz}$ for $2 \mathrm{~min}$ ). Total RNA was isolated with the InviTrap ${ }^{\circledR}$ Spin Plant RNA Mini Kit (STRATEC SE, Birkenfeld). Aliquots of this RNA were treated with Baseline Zero ${ }^{\text {TM }}$ DNase (Biozyme Scientific $\mathrm{GmbH}$, Hessisch Oldendorf) according to the manufacturer's instructions to eliminate contaminating gDNA, purified using the MinElute Cleanup Kit (STRATEC SE, Birkenfeld) and finally photometrically measured (ND-1000, NanoDrop Technologies, Wilmigton, USA). The RNA integrity number values of all RNA samples to be sequenced were determined using a 2100 bioanalyzer (Agilent Technologies, Waldbronn, Germany). Individual RNA samples for transcriptome analysis were converted into 3'-prime specific MACE libraries (Bojahr et al. 2016) and sequenced with 1x 75 b 
bioRxiv preprint doi: https://doi.org/10.1101/2021.02 19.431996; this version posted February 20, 2021. The copyright holder for this preprint (which was not certified by peer review) is the author/funder, who has granted bioRxiv a license to display the preprint in perpetuity. It is made available under aCC-BY-NC 4.0 International license.

reads on a HiSeq 2000 machine (Illumina) resulting in 3,1 - 5 million quality filtered reads. For each line of the NIL pairs, RNA samples which derived from seeds of the developmental stages 4 and 5 were pooled on a ratio of 1:1 and subsequently converted into RNASeq libraries and paired-end sequenced at $2 \times 75$ b on a Hiseq2000 device yielding 64-77 million quality filtered reads per sample. Combined high-quality reads from all samples were used for a de novo assembly and annotation of a duplicate free testa-specific reference transcriptome as described in Santos et al. (2018). The software package JointSNVMix was used to detect single nucleotide variants (Roth et al. 2012). For SNP candidates, a locus must have had at least five reads in both samples where one of two possible bases might occur (either allele A or B). A maximum of one percent false allele reads was tolerated. NGS template preparation, sequencing and bioinformatics took place at GenXPro GmbH (Frankfurt am Main). Transcriptome data evaluation for the identification of SNPs that correlated with the VC phenotype was performed stepwise: for the RNASeq and MACE libraries separately and for each of the two NIL pairs (parents of Cross 1 and Cross 2). For each genotype, MACE-data sets derived from developmental stages 4, 5, and 6 were pooled to increase sensitivity for SNP-detection. Subsequently, those SNP candidates which were common to both NIL pairs were identified.

\section{SNP marker development}

KASP marker development, DNA extraction and KASP analysis were conducted at TraitGenetics (Gatersleben, Germany). KASP assay designs were based on app. 50 bps to the left and right side of SNPs found via the mRNA analysis.

\section{Marker analysis and map construction}

Throughout, the genetic linkage maps were constructed using R (R Development Core Team 2011; R version 3.5.3) and the R package ASMap (Taylor and Butler 2017). For all linkage maps, the Kosambi function was used to calculate the map distances in CM (Kosambi 1943). The functions of the package were used as described by Taylor and Butler (2017).

Missing marker data and marker segregation ratios were identified with the R Package ASMap. Markers that were monomorphic in a cross and markers showing strongly skewed segregations ($\log (\mathrm{P})$ of 2.0 or higher) were excluded from further analyses. The selected SNP markers were used for the linkage map fragment construction.

An initial marker set, which contains markers from Webb et al. 2016, Song et al. 2017, and the group of Donal O Sullivan, yielded the so-called draft maps. These were used to define the putative region of the VC locus for future analyses, especially for the transcription analysis. 
The set of newly developed markers from our transcription analyses and certain markers from the initial marker set (termed new marker set) yielded the final linkage map fragments, which were used for the fine-mapping.

\section{Phenotyping of $\mathrm{VC}$ content for fine-mapping and breeding}

Selected $F_{2}$ individuals from Cross 1 and Cross 2 as well as the backcross generation $B C_{3} F_{2}$ were phenotyped (HPLC; via NIAB 2021). As checks and benchmarks for the HPLC results, $F_{2}$ individuals with marker-deduced homozygous and heterozygous VC genotypes were identified (see Table 1).

Table 1. VC contents of homozygous and heterozygous $F_{2}$ individuals of Cross 1 and Cross 2.

\begin{tabular}{llccccc}
\hline \multicolumn{2}{c}{ Genotype of $\mathbf{F}_{\mathbf{2}}$ individuals } & $\begin{array}{c}\text { No. of } \\
\text { individuals }\end{array}$ & $\begin{array}{c}\text { VC range of } \\
\text { HPLC values }\end{array}$ & $\begin{array}{c}\text { Mean } \\
\text { Cross } \mathbf{1}\end{array}$ & $\begin{array}{c}\text { Standard } \\
\text { error }\end{array}$ & $\begin{array}{c}\text { VC content } \\
\text { category }\end{array}$ \\
\hline & Homozygous HVC & 6 & $0.54-0.89$ & 0.6428 & 0.0502 & HVC \\
& Heterozygous & 8 & $0.47-0.49$ & 0.4798 & 0.0088 & intermediate \\
& Homozygous LVC & 5 & $0.04-0.05$ & 0.0421 & 0.0015 & LVC \\
\hline \multirow{2}{*}{ Cross $\mathbf{2}$} & Homozygous HVC & 4 & $0.51-0.61$ & 0.5520 & 0.0243 & HVC \\
& Heterozygous & 7 & $0.32-0.34$ & 0.3311 & 0.0080 & intermediate \\
& Homozygous LVC & 5 & $0.02-0.03$ & 0.0270 & 0.0020 & LVC \\
\hline
\end{tabular}

\section{Fine mapping}

For the manual fine-mapping of the sought-for VC-locus, phenotypic VC results were displayed along with the SNP genotypes of the $F_{2}$ individuals of Cross 1 and Cross 2. The SNP markers were ordered according to their linkage map positions. The correspondences between genotype and phenotype were thoroughly studied.

\section{BLASTing of SNPs from finemapping}

To determine candidate genes, specific KASP marker sequences which are found within the fine mapped interval were BLASTed against the genomes of $M$. $t$. (LIS - Legume Information System) and of $C$. $a$. to define their physical positions.

\section{Analysis of synteny between Vicia faba and Cicer arietinum}

To determine the synteny between V.f. and $C$. $a$. in the interval-of-interest, the syntenic positions of the markers in the final linkage map fragments on the $C$. $a$. genome were established. For this, the contig DNA sequences from which the new markers were derived and the flanking DNA sequences of the markers from the initial marker set (Webb et al. 2016) were BLASTed against the proteins of the reference sequence of $C$. arietinum (Varshney et al. 2013; NCBI: RefSeq assembly accession no. GCF_000331145.1). BLAST analyses were conducted using the blastx application from the NCBI BLAST+ package (v. 2.7.1). The positions of the transcripts encoding the respective proteins on the reference sequence were extracted from the annotation gff 3 file of the sequence in $\mathrm{R}$ and assigned to the markers as syntenic positions. To extract all transcripts and the corresponding genes and pro- 
bioRxiv preprint doi: https://doi.org/10.1101/2021.02.19.431996; this version posted February 20,2021 . The copyright holder for this preprint (which was not certified by peer review) is the author/funder, who has granted bioRxiv a license to display the preprint in perpetuity. It is made available under aCC-BY-NC 4.0 International license.

teins encoded in the region of the $C$. $a$. genome corresponding to the core region from the annotation file of the reference sequence, the intersect function of bedtools (v2.27.1) was used.

\section{Results}

\section{SNP marker selection}

For the marker-assisted selection, mapping and fine-mapping, markers within the region around the putative VC locus (Khazaei et al. 2015) were chosen and tested. The markers Vf_Mt2g005900_001 and Vf_Mt2g015010_001 from Khazaei et al. (2015) were used to serve as initial boundary markers of the chromosomal to define the initial interval-of-interest and encompass all other chosen markers. In total, six markers from Khazaei et al. (2015), including the initial boundary markers, were chosen. Ten markers from Webb et al. 2016 were added since they were determined to be in the interval-ofinterest according to the physical placement of the initial boundary markers in $M$. $t$. genome and the genetic map of Webb et al. 2016. Additionally, the marker SNP384 from Song (2017) was included.

These 16 markers make up our initial marker set (Table 2) which was used for our first marker assisted selection in the backcross and the construction of draft maps for Cross 1 and Cross 2 .

Table 2. Seventeen SNP markers from Webb et al. 2016, Song 2017 and D. O'Sullivan (initial marker set). Their function in Cross 1 and 2 and for the backcross is noted. Markers in yellow are the initial boundary markers and encompass the chromosomal interval-of-interest. Blue markers denote the region we suspected the VC gene to be located in. Markers are sorted after Webb et al. (2016).

\begin{tabular}{|c|c|c|c|}
\hline \multicolumn{4}{|c|}{ Usability in families } \\
\hline SNP-Marker & Cross 1 & Cross 2 & Backcross \\
\hline Vf_Mt2g005900_001* & $x$ & - & $x$ \\
\hline Vf_Mt1g083330_001* & $x$ & - & - \\
\hline Vf_Mt2g007220_001* & $x$ & - & - \\
\hline Vf_Mt2g007390_001 & - & $x$ & $x$ \\
\hline Vf_Mt2g008150_001 & - & $x$ & - \\
\hline Vf_Mt2g008180_001 & $\mathrm{x}$ & - & - \\
\hline Vf_Mt2g008226_001 & $x$ & - & - \\
\hline Vf_Mt2g009230_001 & - & - & - \\
\hline SNP384 & $x$ & $x$ & $x$ \\
\hline Vf_Mt2g009320_001 & $x$ & $\#$ & $x$ \\
\hline Vf_Mt2g010740_001* & $x$ & $\#$ & $x$ \\
\hline Vf_Mt2g010880_001* & $x$ & - & - \\
\hline Vf_Mt2g010970_001 & - & $\#$ & - \\
\hline Vf_Mt2g011080_001 & - & - & $x$ \\
\hline Vf_Mt2g013690_001 & - & $x$ & - \\
\hline Vf_Mt2g013900_001 & - & - & $x$ \\
\hline Vf_Mt2g015010_001 * & - & - & - \\
\hline
\end{tabular}


Only subsets of the 16 markers (initial marker set) were polymorphic in the respective genetic backgrounds (Table 2). Most notably, the marker Vf_Mt2g015010_001, which served as initial boundary marker, was monomorphic. The polymorphic marker Vf_Mt2g013690_001 was hence chosen as substitute (see Table 2). So, markers Vf_Mt2g005900_001 and Vf_Mt2g013690_001 were subsequently used to define the search frame (Table 3). All markers polymorphic in Cross 1 and Cross 2 were used for the construction of the draft maps. Only three markers were polymorphic in all genetic backgrounds (Table 2, markers SNP384, Vf_Mt2g009320_001 and Vf_Mt2g010740_001) and their chromosomal vicinity was deemed as the most likely region to contain the VC gene, based on the data of Song (2017) and Khazaei et al. (2017), and was therefore the focus for our search for new SNP markers and the VC gene in the transcription analysis. In addition, the markers polymorphic in the backcross were used for marker assisted selection in the backcrossing program.

Analysis of RNAseq and MACE data sets revealed, in the intersection of Cross 1 and Cross 2, a total of 448 unique SNPs within 123 contigs (Table 3). These contigs could be assigned to chromosome 2 of M. truncatula. Of these, 135 unique SNPs from 35 contigs were found within the new interval-ofinterst. A total of 73 SNPs were found with both analyses, RNAseq and MACE.

Table 3. Comparison of LVC vs. HVC data from transcription analysis of Cross $\mathbf{1}$ and Cross $\mathbf{2}$. Given are the numbers of detected SNPs and contigs which were found with different transcription analysis methods and search frames.

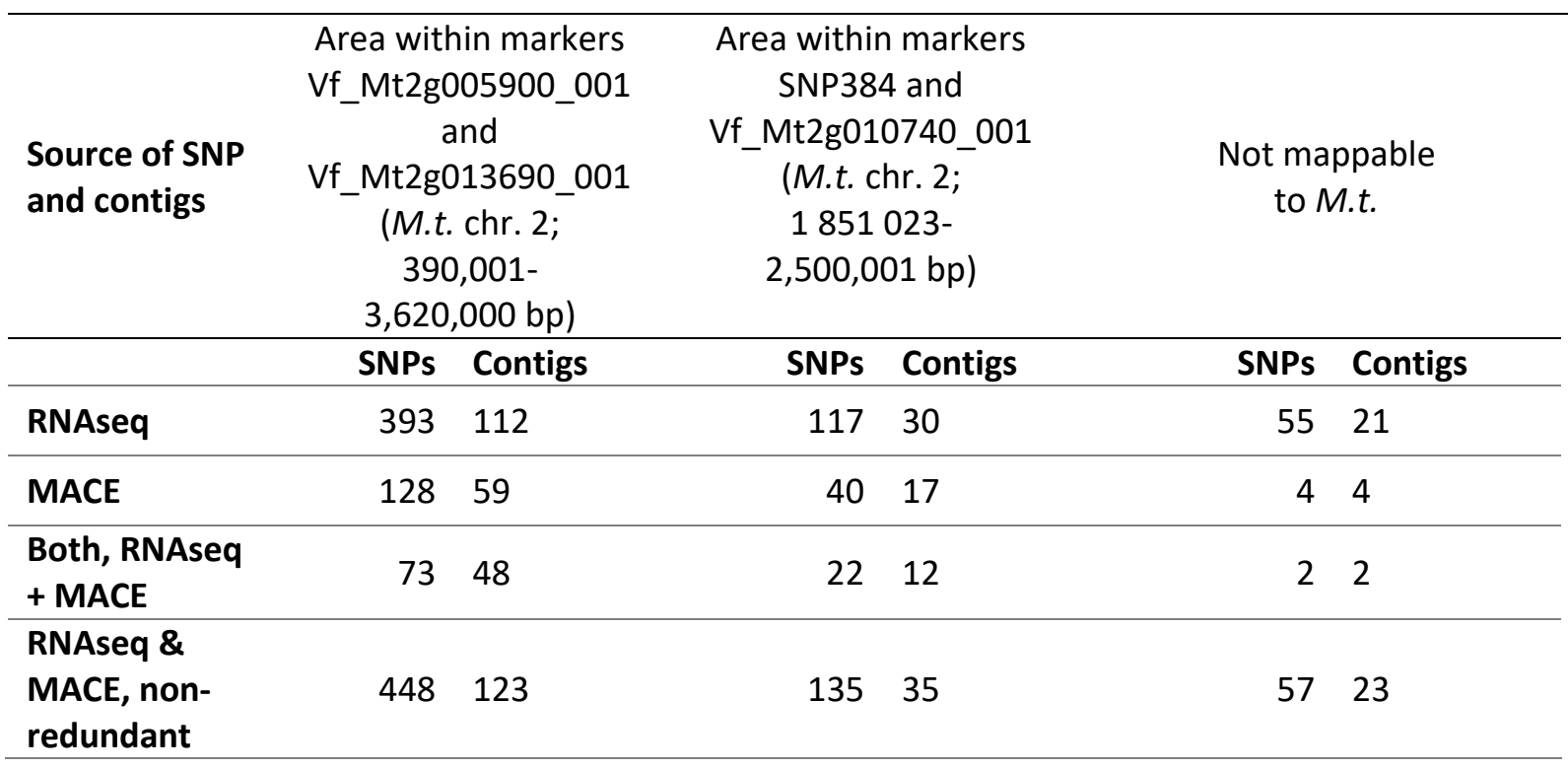

From this data, new markers were developed (Table 4), preferably from those 448 SNP candidates which mapped to the area and within markers Vf_Mt2g005900_001 and Vf_Mt2g013690_001 (M.t. chr. 2; 390,001-3,620,000 bp, see Table 3). 
Table 4. Fifty-eight SNP markers from mRNA analyses RNAseq and MACE. Their origin as well as their function in the three families (Cross 1 and 2 and backcross) is noted.

\begin{tabular}{|c|c|c|c|c|}
\hline Marker & Filtering process & Cross 1 & Cross? & Back-cross \\
\hline VFS18002.A03 & \multirow{33}{*}{$\begin{array}{l}\text { Taken from the } 73 \text { SNP markers } \\
\text { found with both techniques, RNAseq } \\
\text { and MACE (Table } 3 \text { ) }\end{array}$} & $\mathrm{X}$ & $\mathrm{X}$ & - \\
\hline VFS18002.A04 & & $\mathrm{x}$ & $\mathrm{x}$ & $\mathrm{x}$ \\
\hline VFS18002.A05 & & $\mathrm{x}$ & $\mathrm{x}$ & - \\
\hline VFS18002.A06 & & $\#$ & $x$ & $x$ \\
\hline VFS18002.A07 & & $\mathrm{X}$ & $x$ & $x$ \\
\hline VFS18002.A08 & & $\mathrm{X}$ & $\mathrm{X}$ & $\mathrm{X}$ \\
\hline VFS18002.A09 & & \# & \# & $\mathrm{X}$ \\
\hline VFS18002.A10 & & \# & \# & - \\
\hline VFS18002.A11 & & - & - & - \\
\hline VFS18002.A12 & & $x$ & $x$ & $x$ \\
\hline VFS18002.A13 & & $\mathrm{X}$ & $\mathrm{X}$ & $\mathrm{X}$ \\
\hline VFS18002.A14 & & $\mathrm{x}$ & $\mathrm{x}$ & $\mathrm{X}$ \\
\hline VFS18002.A15 & & $x$ & $x$ & - \\
\hline VFS18002.A16 & & $x$ & $x$ & $x$ \\
\hline VFS18002.A17 & & $x$ & $x$ & $x$ \\
\hline VFS18002.A18 & & \# & \# & - \\
\hline VFS18002.A19 & & $x$ & $x$ & $x$ \\
\hline VFS18002.A20 & & - & - & - \\
\hline VFS18002.A21 & & $x$ & $\#$ & $x$ \\
\hline VFS18002.A22 & & - & - & - \\
\hline VFS18002.A23 & & - & - & - \\
\hline VFS18002.A24 & & $x$ & $x$ & - \\
\hline VFS18002.A25 & & - & - & - \\
\hline VFS18002.A26 & & $x$ & - & - \\
\hline VFS18002.A27 & & $\#$ & $\#$ & - \\
\hline VFS18002.A28 & & $x$ & - & $x$ \\
\hline VFS18002.A29 & & $x$ & $\#$ & $x$ \\
\hline VFS18002.A30 & & $x$ & $x$ & $x$ \\
\hline VFS18002.A31 & & $x$ & $x$ & - \\
\hline VFS18002.A32 & & $x$ & $x$ & - \\
\hline VFS18002.A33 & & $x$ & $\#$ & - \\
\hline VFS18002.A34 & & $x$ & $x$ & - \\
\hline VFS18002.A35 & & $x$ & $x$ & $x$ \\
\hline VFS18002.A36 & \multirow{13}{*}{$\begin{array}{l}\text { From MACE \& RNAseq-data, not } \\
\text { mappable to M.t. }\end{array}$} & $\#$ & - & - \\
\hline VFS18002.A37 & & $x$ & - & $x$ \\
\hline VFS18002.A38 & & $\mathrm{X}$ & $x$ & $x$ \\
\hline VFS18002.A39 & & $\mathrm{X}$ & $\mathrm{X}$ & $x$ \\
\hline VFS18002.A40 & & $x$ & $x$ & $x$ \\
\hline VFS18002.A41 & & $x$ & $x$ & $x$ \\
\hline VFS18002.A42 & & $x$ & $x$ & $x$ \\
\hline VFS18002.A43 & & $x$ & $x$ & $x$ \\
\hline VFS18002.A44 & & - & $\#$ & $x$ \\
\hline VFS18002.A45 & & - & - & - \\
\hline VFS18002.A46 & & - & $x$ & - \\
\hline VFS18002.A47 & & $\#$ & $x$ & $x$ \\
\hline VFS18002.A48 & & $x$ & $x$ & $x$ \\
\hline
\end{tabular}




\begin{tabular}{|c|c|c|c|c|}
\hline VFS18002.A49 & \multirow{12}{*}{ From RNAseq only, mapped to M.t. } & $x$ & $x$ & $x$ \\
\hline VFS18002.A50 & & \# & - & $x$ \\
\hline VFS18002.A51 & & $X$ & $x$ & $x$ \\
\hline VFS18002.A52 & & $x$ & $x$ & $x$ \\
\hline VFS18002.A53 & & $X$ & $x$ & - \\
\hline VFS18002.A54 & & $x$ & $x$ & $x$ \\
\hline VFS18002.A55 & & $x$ & $x$ & $x$ \\
\hline VFS18002.A56 & & $x$ & $\#$ & - \\
\hline VFS18002.A57 & & $x$ & $x$ & $x$ \\
\hline VFS18002.A58 & & $x$ & $x$ & - \\
\hline VFS18002.A59 & & $x$ & $x$ & - \\
\hline VFS18002.A60 & & $x$ & $x$ & $x$ \\
\hline
\end{tabular}

"- ": not polymorphic; "\#”: removed from the analysis due to skewed segregation patterns; " $X$ " used in final genetic maps and for marker assisted selection

Of the 58 newly developed markers, 42 markers were used for the construction of the final linkage map fragment and fine-mapping of Cross 1 and 38 markers were used for Cross 2 (see Table 1), since these were polymorphic and did not show skewed segregation patterns. For the backcross, 34 markers were polymorphic and were tested for their suitability for our further winter bean breeding. Those of the initial set markers which were polymorphic for the genetic backgrounds of Cross 1 and 2 plus the above described newly developed markers form the new marker set.

\section{Linkage maps}

For the construction of the draft linkage maps, all $F_{2}$ genotypes present in the $F_{2}$ families were used, i.e., 751 individuals for Cross 1, and 899 individuals for Cross 2. The initial marker set that was employed for draft maps is depicted in Table 2. The marker order in the draft maps followed nearly always the order of their physical placement in the genome sequence of $M$. truncatula. The new marker set gave the final linkage map fragments for Cross 1 and Cross 2.

Only informative $F_{2}$ genotypes were genotyped with the new marker set. Such informative $F_{2}$ genotypes had one or more putative recombination events as determined by their marker genotypes and the draft mapping. A total of 70 individuals for Cross 1 and 74 individuals for Cross 2 were thus reanalyzed with the new marker set. In addition, and as controls, the parental genotypes (10 plants each) of the respective cross were genotyped with the new marker set. The marker data of the remaining $F_{2}$ individuals were inferred based on results from the draft maps.

SNP results of the informative and control individuals were checked for missing data points and for plausibility of their numbers of single and double crossovers. Five $F_{2}$-individuals of Cross 1 and nine of Cross 2 were excluded based on more than 10 missing marker data per individual and on extremely unlikely recombination patterns, such as the apparent occurrence of two or more crossovers in both gametes within $3 \mathrm{cM}$. This cleansing combined with exclusion of markers with strongly skewed seg- 
bioRxiv preprint doi: https:/doi org/10.1101/2021.02 19.431996; this version posted February 20, 2021. The copyright holder for this preprint (which was not certified by peer review) is the author/funder, who has granted bioRxiv a license to display the preprint in perpetuity. It is made available under aCC-BY-NC 4.0 International license.

regations (see "SNP marker selection", Table 4) reduced the length of the map fragments from app. $20 \mathrm{cM}$ in a first, uncleansed approach to between 3 and $6 \mathrm{cM}$ for the final linkage map fragments.

\section{Cross 1}

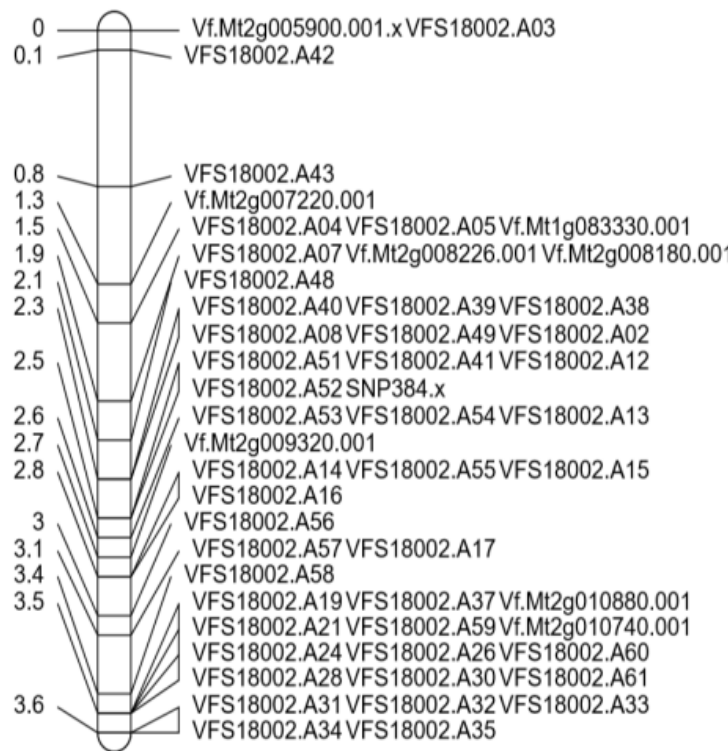

\section{Cross 2}

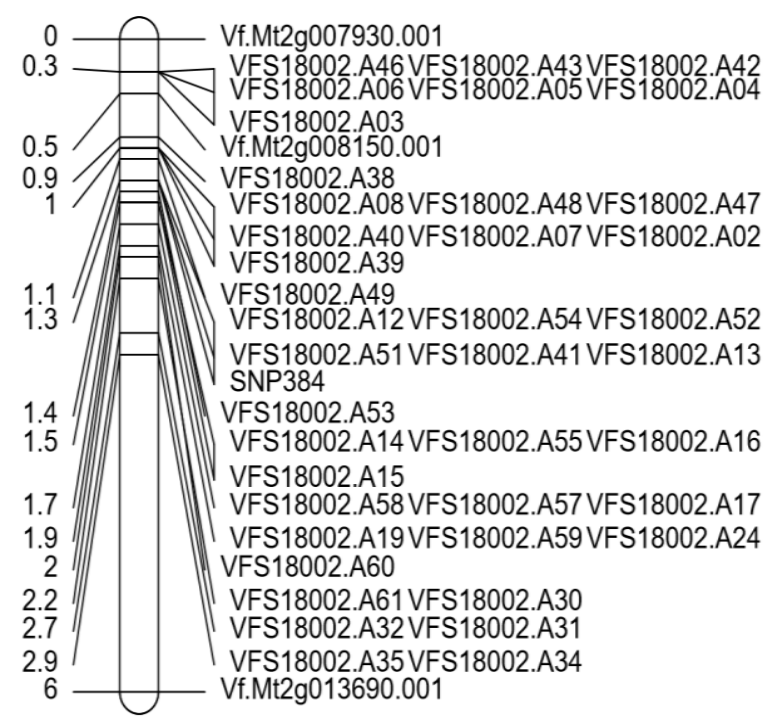

Figure 2. Final linkage map fragments for Cross 1 and Cross 2. Depicted are fragments of chromosome 1 of $V$.f. showing the putative region of the VC locus. Positions of markers are given in $\mathrm{CM}$ on the left, marker names for the respective positions are given on the right.

\section{Fine mapping of the VC locus}

For the manual fine-mapping of the sought-for VC-locus, the informative $F_{2}$ plants of Cross 1 and Cross 2 were phenotyped for their VC content.

The resulting VC phenotypes were matched with the genotypes. For this purpose, markers were arranged according to the final linkage map fragments $s$ (Figure 2). The $F_{2}$ individuals were grouped as homozygous HVC, heterozygous and homozygous LVC. Crossovers were thus made visible (see Tables $5 \mathrm{~A}$ and $5 \mathrm{~B})$.

It was hence determined which crossovers were closest to the VC locus (see Tables 5A and 5B). The smallest possible SNP interval bearing the sought-for VC locus was determined for both crosses. This interval is referred to as the core region (depicted by orange background of marker names in Tables $5 A$ and $5 B)$. 
Table 5A. Fine-mapping of the vicinity of the VC locus for Cross $1 . F_{2}$ genotypes of the respective individuals are sorted according to their haplotypes, with homozygous for SNP-allele (green, A) as detected in LVC parent on the left to heterozygous (yellow, $\mathrm{H}$ ) in the middle to homozygous for SNPalleles (red, B) as detected in HVC parent on the right. The respective HPLC VC contents are given above with the individual numbers of genotypes. Marker names as well as their positions on the genetic linkage map fragments (see Figure 2) are displayed, thus crossovers are visualized. Orange colored marker names define outer boundaries of the interval which, according to this fine-mapping, contains the VC locus. The light green colored marker name depicts the SNP384 which was defined by Khazaei et al. (2017) as a diagnostic marker for VC content.

\begin{tabular}{|c|c|c|c|c|c|c|c|}
\hline \multirow{4}{*}{$\begin{array}{l}\text { Pos. in } \\
\text { genetic } \\
\text { map } \\
\text { (cM) }\end{array}$} & \multirow{4}{*}{ Marker } & \multicolumn{6}{|c|}{$F_{2}$ individuales } \\
\hline & & 587 & 273 & 440 & 765 & 404 & 313 \\
\hline & & \multicolumn{6}{|c|}{ VC content (HPLC; Total \% Vicine/convicine (dry weight)) } \\
\hline & & 0.0459 & 0.0436 & 0.4832 & 0.4678 & 0.5824 & 0.5606 \\
\hline & & \multicolumn{6}{|c|}{ Marker genotypes } \\
\hline 2.28 & VFS18002.A39 & A & H & A & $\mathbf{H}$ & B & H \\
\hline 2.28 & VFS18002.A49 & A & H & A & $\mathbf{H}$ & B & H \\
\hline 2.48 & VFS18002.A51 & A & A & A & $\mathbf{H}$ & B & B \\
\hline 2.55 & VFS18002.A41 & A & A & H & $\mathbf{H}$ & B & B \\
\hline 2.55 & VFS18002.A12 & A & A & H & H & B & B \\
\hline 2.55 & VFS18002.A52 & A & A & H & $\mathbf{H}$ & B & B \\
\hline 2.55 & SNP384 & A & A & H & $\mathbf{H}$ & B & B \\
\hline 2.61 & VFS18002.A54 & A & A & $\mathbf{H}$ & $\mathrm{H}$ & $\mathbf{H}$ & B \\
\hline 2.61 & VFS18002.A13 & A & A & H & $\mathbf{H}$ & $\mathrm{H}$ & B \\
\hline 2.61 & VFS18002.A53 & A & A & H & H & $\mathbf{H}$ & B \\
\hline 2.68 & Vf.Mt2g009320 & A & A & H & H & $\mathbf{H}$ & B \\
\hline 2.75 & VFS18002.A14 & A & A & $\mathbf{H}$ & A & H & B \\
\hline 2.75 & VFS18002.A55 & A & A & H & A & H & B \\
\hline
\end{tabular}

Table 5B. Fine-mapping of the vicinity of the VC locus for Cross 2.

\begin{tabular}{|c|c|c|c|c|c|c|c|}
\hline \multirow{4}{*}{$\begin{array}{l}\text { Pos. in } \\
\text { genetic } \\
\text { map } \\
\text { (cM) }\end{array}$} & \multirow{4}{*}{ Marker } & \multicolumn{6}{|c|}{$F_{2}$ individuales } \\
\hline & & 223 & 589 & 11 & 129 & 267 & 885 \\
\hline & & \multicolumn{6}{|c|}{ VC content (HPLC; Total \% Vicine/convicine (dry weight)) } \\
\hline & & 0.0309 & 0.0305 & 0.3197 & 0.3425 & 0.5101 & 0.5363 \\
\hline & & \multicolumn{6}{|c|}{ Marker genotypes } \\
\hline 0.98 & VFS18002.A39 & A & A & $\mathbf{H}$ & $\mathbf{H}$ & H & B \\
\hline 1.10 & VFS18002.A49 & A & A & H & $\mathbf{H}$ & H & B \\
\hline 1.26 & VFS18002.A51 & A & A & H & $\mathbf{H}$ & B & B \\
\hline 1.26 & VFS18002.A41 & A & A & H & H & B & B \\
\hline 1.26 & VFS18002.A12 & A & A & H & H & B & B \\
\hline 1.26 & VFS18002.A52 & A & A & H & H & B & B \\
\hline 1.26 & SNP384 & A & A & H & H & B & B \\
\hline 1.26 & VFS18002.A54 & A & A & H & H & B & B \\
\hline 1.26 & VFS18002.A13 & A & A & H & H & B & B \\
\hline 1.37 & VFS18002.A53 & A & $\mathrm{H}$ & $\mathrm{H}$ & H & B & B \\
\hline 1.49 & VFS18002.A14 & A & H & $\mathrm{H}$ & B & B & B \\
\hline 1.49 & VFS18002.A55 & A & H & H & B & B & B \\
\hline
\end{tabular}


bioRxiv preprint doi: https://doi.org/10.1101/2021.02.19.431996; this version posted February 20, 2021. The copyright holder for this preprint (which was not certified by peer review) is the author/funder, who has granted bioRxiv a license to display the preprint in perpetuity. It is made available under aCC-BY-NC 4.0 International license.

The region between markers VFS18002.A51 and VFS18002.A54 (Cross 1) was 0.14cM smaller than the region between markers VFS18002.A49 and VFS18002.A53 (Cross 2; Table 5A, 5B). All markers in this Cross 1 region were included in the region of Cross 2, and in same order. VFS18002.A51 and VFS18002.A54 of Cross 1 (0.13cM) are consequently the final boundary markers which define the core region where the VC locus must be located.

SNP marker validation for breeding novel, winterhardy, vc- faba bean lines Those nine markers which are denominated by the outer boundaries of the intervals in Cross 1 and Cross 2 (see Tables $5 A$ and $5 B$ ) were tested in our backcross material to confirm markers which might be good candidates for marker assisted selection. The usability of these markers for the backcross material and the accuracy of the respective marker prediction for the VC content was verified with $\mathrm{BC}_{3} \mathrm{~F}_{2}$ genotypes and their respective HPLC results.

Eight of these promising nine markers (see Tables 5A and 5B) proved to be precise selection tools for our backcrossing program, namely markers VFS18002.A49 to VFS18002.A13 (see Table 6) while one marker was not polymorphic here (VFS18002.A53). Two markers did not perfectly match; they were indeed not included in this group of promising markers (markers VFS18002.A14 and VFS18002.A55; see Table 6).

Table 6. Markers tested for marker-assisted selection potential in Hiverna/2 * Mélodie/2 backcross material. Markers were selected from the fine-mapping of Cross 1 and Cross 2 . They are ordered according to the fine-map of Cross 1.

\begin{tabular}{|c|c|c|c|c|c|c|c|c|c|c|c|c|}
\hline \multirow{4}{*}{ Marker } & \multicolumn{12}{|c|}{$\mathrm{F}_{2}$ individuales of Hiverna/2 $*$ Mélodie/2 backcross generation $\mathrm{BC}_{3}$} \\
\hline & \multicolumn{12}{|c|}{ VC content (HPLC; Total \% Vicine/convicine (dry weight)) } \\
\hline & 0.0306 & 0.0373 & 0.0396 & 0.0353 & 0.4060 & 0.4079 & 0.4146 & 0.5482 & 0.5539 & 0.5955 & 0.6031 & 0.6285 \\
\hline & \multicolumn{12}{|c|}{ Marker genotypes } \\
\hline VFS18002.A49 & A & A & A & A & 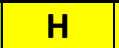 & $\mathbf{H}$ & $\mathbf{H}$ & B & B & B & B & B \\
\hline VFS18002.A51 & A & A & A & A & $\mathbf{H}$ & H & H & B & B & B & B & B \\
\hline VFS18002.A41 & A & A & A & A & $\mathbf{H}$ & $\mathbf{H}$ & $\mathbf{H}$ & B & B & B & B & B \\
\hline VFS18002.A12 & A & A & A & A & $\mathbf{H}$ & $\mathbf{H}$ & $\mathbf{H}$ & B & B & B & B & B \\
\hline VFS18002.A52 & A & A & A & A & $\mathbf{H}$ & $\mathbf{H}$ & $\mathbf{H}$ & B & B & B & B & B \\
\hline SNP384 & A & A & A & A & $\mathbf{H}$ & $\mathbf{H}$ & $\mathbf{H}$ & B & B & B & B & B \\
\hline VFS18002.A54 & A & A & A & A & H & H & H & B & B & B & B & B \\
\hline VFS18002.A13 & A & $A$ & $A$ & $\mathrm{~A}$ & $\mathbf{H}$ & $\mathbf{H}$ & $\mathbf{H}$ & B & B & B & B & B \\
\hline VFS18002.A53 & \multicolumn{12}{|c|}{ Monomorphic in the backcross material } \\
\hline VFS18002.A14 & A & A & A & $\mathbf{H}$ & $\mathbf{H}$ & $\mathbf{H}$ & $\mathbf{H}$ & B & B & B & B & B \\
\hline VFS18002.A55 & A & A & A & $\mathbf{H}$ & $\mathbf{H}$ & $\mathbf{H}$ & $\mathbf{H}$ & B & B & B & B & B \\
\hline
\end{tabular}

\section{Putative candidate genes from synteny studies and from transcriptome analyses}

The core region which was identified via fine-mapping of Cross 1 and Cross 2 was inspected for possible candidate genes. The sequences of the markers covering the core region were BLASTed against 
the genomes of M.t. and C.a. (see Table 7) and genes within the core region were noted (see Table 8).

Table 7. Markers of core-region and their positions in the M.t. genome.

\begin{tabular}{ccc}
\hline Position in V.f. (cM) & Marker name & Positon in M.t. (bp) \\
\hline $\mathbf{2 . 4 8}$ & VFS18002.A51 & 1764 412 \\
\hline $\mathbf{2 . 5 5}$ & VFS18002.A41 & no match on Chr. 2 \\
\hline $\mathbf{2 . 5 5}$ & VFS18002.A12 & 1828300 \\
\hline $\mathbf{2 . 5 5}$ & VFS18002.A52 & 1852191 \\
\hline $\mathbf{2 . 5 5}$ & SNP384 & 1851023 \\
\hline $\mathbf{2 . 6 1}$ & VFS18002.A54 & 1974254 \\
\hline
\end{tabular}

A total of 30 genes were thus found in M.t., while a subset of 17 of these could also be found in the corresponding region of C.a. (Table 8).

The expression analyses revealed that only one gene found in the core-region was differentially expressed (Abo-Vici 2021), namely 3,4-dihydroxy-2-butanone 4-phosphate synthase (or Riboflavin biosynthesis protein, ribBA)).

Table 8. Genes located in the region of M.t. and C.a. syntenic to the core region in Vicia faba.

\begin{tabular}{|c|c|c|c|}
\hline Gene name & $\begin{array}{l}\text { Start posi- } \\
\text { tion M.t. } \\
\text { genome } \\
\text { (bp) }\end{array}$ & Product & $\begin{array}{l}\text { Assessable in } \\
\text { C.a. core region } \\
\text { equivalent }\end{array}$ \\
\hline MTR_2g009090 & 1771882 & Splicing factor 3B subunit, putative & - \\
\hline MTR_2g009110 & 1780752 & Splicing factor 3B subunit 1 & Yes \\
\hline MTR_2g009130 & 1796938 & Hypothetical protein & - \\
\hline MTR_2g009140 & 1801324 & DNA (cytosine-5)-methyltransferase & Yes \\
\hline MTR_2g009150 & 1807363 & Transmembrane protein, putative & - \\
\hline MTR_2g009190 & 1810285 & $\begin{array}{l}\text { Minichromosome maintenance (MCM2/3/5) fam- } \\
\text { ily protein }\end{array}$ & Yes \\
\hline MTR_2g009200 & 1822351 & Serine carboxypeptidase-like protein & - \\
\hline MTR_2g009220 & 1828042 & 2-oxoglutarate/malate translocator & Yes \\
\hline MTR_2g00923 & 1833036 & L-ascorbate oxidase & - \\
\hline MTR_2g009270 & 1.848 .020 & 3,4-dihydroxy-2-butanone 4-phosphate synthase & Yes \\
\hline MTR_2g009275 & 1854017 & Transmembrane protein, putative & Yes \\
\hline MTR_2g009290 & 1860925 & Transmembrane protein, putative & - \\
\hline MTR_2g009310 & 1866319 & RING-H2 zinc finger protein & Yes \\
\hline MTR_2g009320 & 1869086 & Ubiquinol-cytochrome $\mathrm{C}$ chaperone protein & Yes \\
\hline MTR_2g009330 & 1877274 & Pyruvate decarboxylase & Yes \\
\hline MTR_2g009340 & 1883129 & Phototropic-responsive NPH3 family protein & Yes \\
\hline MTR_2g009360 & 1890536 & Transcription factor & Yes \\
\hline MTR_2g009390 & 1899088 & FKBP-type peptidyl-prolyl cis-trans isomerase & Yes \\
\hline MTR_2g009410 & 1904618 & Oligosaccaryltransferase & - \\
\hline
\end{tabular}




\begin{tabular}{lllc}
\hline MTR_2g009415 & 1905205 & tRNA-His & Yes \\
\hline MTR_2g009430 & 1911762 & Hypothetical protein & - \\
\hline MTR_2g009450 & 1915096 & Leguminosin group485 secreted peptide & Yes \\
\hline MTR_2g009480 & 1929386 & Leguminosin group485 secreted peptide & Yes \\
\hline MTR_2g009500 & 1937541 & Carbonic anhydrase family protein & Yes \\
\hline MTR_2g009520 & 1948713 & Chaperone DnaJ-domain protein & - \\
\hline MTR_2g009530 & 1952263 & Hypothetical protein & - \\
\hline MTR_2g009550 & 1957898 & ATP synthase subunit beta, putative & - \\
\hline MTR_2g009560 & 1958801 & FOF1 ATP synthase subunit beta & - \\
\hline MTR_2g009590 & 1975139 & Hydroxyproline-rich glycoprotein family protein & Yes \\
\hline
\end{tabular}

\section{Breeding progress of novel, winter hardy, vc- faba bean lines}

The backcrossing program, with the selection based on hilum colour and on HPLC results to breed a winter hardy, LVC faba bean line was carried out until 2017 and up to generation $\mathrm{BC}_{3} \mathrm{~F}_{2}$. Thereafter, KASP markers were employed (Khazaei et al. 2015; Webb et al. 2015). Starting in 2018, we employed KASP markers derived from our transcription analyses. KASP marker predictions were verified by $\mathrm{HPLC}$ results. Our markers allowed to identify $\mathrm{VC}+/ \mathrm{vc}$ - heterozygous $\mathrm{BC}_{4} \mathrm{~F}_{1}$ plants and directly employ them for further backcrossing (instead of using $\mathrm{BC}_{4} \mathrm{~F}_{3}$ ), thus we could very markedly speed up the process.

In 2018, the genetic diversity of the backcrossing program was widened. Selected $\mathrm{BC}_{3} \mathrm{~F}_{2}$ individuals (Tacke and Link, 2018) were crossed with non-Hiverna/2 winter lines: S_062, S_300, S_306 and S_340 (Gasim and Link, 2007). These lines were chosen for their superior winter hardiness and agronomic performance at Göttingen.

In 2020, we arrived at generation $\mathrm{BC}_{4} \mathrm{~F}_{4}$. From this material, four LVC components (see Table 9) were sown in October 2019 as generation Syn 0 and in October 2020 as Syn 1, to initiate a novel LVC synthetic variety of winter faba beans as experimental cultivar and as breeding germplasm pool.

Table 9. Four LVC components were used to initiate Syn0 of a winter hardy, LVC synthetic population.

\begin{tabular}{cccc}
\hline $\begin{array}{c}\text { Internal field book } \\
\text { numbers }\end{array}$ & $\begin{array}{c}\text { Backcross } \\
\text { generation }\end{array}$ & Detailed pedigree & $\begin{array}{c}\text { Component } \\
\text { in Syn 0 }\end{array}$ \\
\hline F19_[622-631] & BC4F4 & BC4F4(S_062*BC3F2(Hiv/2*Mél/2)) & 1 \\
\hline F19_[633-638] & BC4F4 & BC4F4(S_300*BC3F2(Hiv/2*Mél/2)) & 2 \\
\hline F19_[675-698] & BC4F4 & BC3F4(S_306*BC2F2(Hiv/2*Mél/2)) & 3 \\
\hline F19_[702-720] & BC3F4 & BC3F4(S_340*BC2F2(Hiv/2* Mél/2)) & 4 \\
\hline
\end{tabular}


bioRxiv preprint doi: https://doi.org/10.1101/2021.02 19.431996; this version posted February 20, 2021. The copyright holder for this preprint (which was not certified by peer review) is the author/funder, who has granted bioRxiv a license to display the preprint in perpetuity. It is made available under aCC-BY-NC 4.0 International license.

\section{Discussion}

In 2015, Khazaei et al. published a genetic map of the fragment of faba bean chromosome 1 which most likely contains the VC locus. This was the first mapping attempt of this locus and the VC gene. It reduced the search area for the causative gene down to approximately 4cM. For this, the authors employed a set of $210 \mathrm{~F}_{5}$ recombinant inbred lines (RILs) of a cross between Mélodie/2, a LVC inbred line, and ILB938/2, a HVC inbred line. Genotyping was done with a set of 188 polymorphic SNPs (Khazaei et al. 2015).

Gutiérrez et al. (2016) reported corresponding findings from their cross Vf6 * 1268. The putative region of the respective locus in their approach amounts also to app. 4cM. We employed two crosses with two different genetic backgrounds containing 751 and 899 individuals, respectively. Sixteen markers from Webb et al. (2016) and Song (2017) allowed the draft mapping. Via mRNA analyses, 58 new markers were developed, 42 and 38 of which were polymorphic for the two genetic backgrounds and were thus used for the creation of final genetic linkage map fragments. The two resulting maps show, for those markers which were also used by Khazaei et al. (2017), the almost same order. The so far empty gaps between those markers are now enriched with 42 and 38 new markers, respectively. The subsequent fine mapping resulted in a core region for the VC gene of app. only 0.13 cM.

The relatively small area of this core region yielded a set of putative candidates. Additionally, our approach towards a candidate gene via expression analysis also yielded a set of candidates, which were differentially expressed in immature seed coat tissue of our LVC and HVC NIL pairs.

The overlap between the two approaches clearly indicated that the most likely VC candidate gene was 3,4-dihydroxy-2-butanone 4 -phosphate synthase, or bifunctional riboflavin biosynthesis protein RIBA 1. Recently, Björnsdotter et al. (2020) named the gene RIBA 1 as the putative candidate gene for the vc- phenotype. Their findings strongly suggest that vicine and convicine are side products of the riboflavin biosynthesis from the purine GTP. Their hypothesis for the cause of the LVC phenotype is a frame shift insertion in the RIBA1 enzyme. They accordingly named the gene for the RIBA1 enzyme VC1. Our findings seem to verify the conclusion of Björnsdotter et al. (2020).

Additionally, the mRNA analyses lead to a set of new markers in the VC core region, ready for use for marker assisted selection. We employed them and bred new, LVC winter faba bean lines, aiming at highly versatile feed stuff from highly productive winter beans. Syn 1 of the first, novel LVC winter faba bean variety is currently (2021 season) in the field. This introduction of the LVC feature will make winter faba beans more attractive for farmers and feed producers. 


\section{Acknowledgements}

We very thankfully acknowledge funding of this project by BLE/BMEL (Abo-Vici, FKZ 2815EPS004). We acknowledge the very helpful donations of $\mathrm{F}_{5}$-individuals of Cross 1 (University Helslinki) and of Cross 2 (NPZ Lembke KG) to the Abo-Vici project. Donal O'Sullivan and Deepti Angra gave us the initial marker set; we thank them indeed. We would like to thank Helen Appleyard at NIAB for the very many HLPC analyses and very efficient cooperation. Finally, we would like to express our thankfulness to the team at Georg-August University of Göttingen, and especially to Regina March and Sonja Yaman.

\section{Literature}

Abo-Vici consortium (2021): "Aktuelles" of Abo-Vici project. In: https://www.unigoettingen.de/de/566949.html, last checked on 18.02.21

Annicchiarico, P.; Nazzicari, N.; Wei, Y.; Pecetti, Luciano; Brummer, Edward C. (2017): Genotyping-bySequencing and Its Exploitation for Forage and Cool-Season Grain Legume Breeding. In: Frontiers in plant science 8, pp. 679. DOI: 10.3389/fpls.2017.00679.

Arese, P. (2006): How genetics and biology helped humanity to survive falciparum malaria. In: Parassitologia 48 (4), pp. 553-559.

Arese, P.; Gallo, V.; Pantaleo, A.; Turrini, F. (2012): Life and Death of Glucose-6-Phosphate Dehydrogenase (G6PD) Deficient Erythrocytes - Role of Redox Stress and Band 3 Modifications. In: Transfusion Medicine and Hemotherapy 39 (5), pp. 328-334. DOI: 10.1159/000343123.

Björnsdotter, E.; Nadzieja, M.; Chang, W.; Escobar-Herrera, L.; Mancinotti, D.; Angra, D.i. et al. (2020): VC1 catalyzes a key step in the biosynthesis of vicine from GTP in faba bean. In: bioRxiv, 2020.02.26.966523. DOI: 10.1101/2020.02.26.966523.

Bojahr, J.; Nhengiwa, O.; Krezdorn, N.; Rotter, B.; Saal, B.; Ruge-Wehling, B.; Struck, C.; Winter, P. (2016): Massive analysis of cDNA ends (MACE) reveals a co-segregating candidate gene for LpPg1 stem rust resistance in perennial ryegrass (Lolium perenne). In: Theor. Appl. Genet. Vol. 129(10), pp. 1915-32. DOI: 10.1007/s00122-016-2749-4.

Borisjuk, L.; Weber, H.; Panitz, R; Manteuffel, R.; Wobus, U. (1995): Embryogenesis of Vicia faba L.: Histodifferentiation in Relation to Starch and Storage Protein Synthesis. In: Plant Physiol. Vol. 147. pp. 203-218.

Brown, E. G.; Roberts, F. M. (1972): Formation of vicine and convicine by Vicia faba. In: Phytochemistry 11 (11), pp. 3203-3206. DOI: 10.1016/S0031-9422(00)86374-8.

Bundessortenamt 2019: Beschreibende Sortenliste. In: ISSN 21 90-61 30. See online at https://www.topagrar.com/acker/news/beschreibende-sortenlisten-2019-veroeffentlicht11684878.html, last checked on 17.02.2021. 
bioRxiv preprint doi: https://doi.org/10.1101/2021.02.19.431996; this version posted February 20, 2021. The copyright holder for this preprint (which was not certified by peer review) is the author/funder, who has granted bioRxiv a license to display the preprint in perpetuity. It is made available under aCC-BY-NC 4.0 International license.

Crépon, K.; Marget, P.; Peyronnet, C.; Carrouée, B.; Arese, P.; Duc, G. (2010): Nutritional value of faba bean (Vicia faba L.) seeds for feed and food. In: Fields Crops Research (115), pp. 329-339.

Cruz-Izquierdo, S.; Avila, C. M.; Satovic, Z.; Palomino, C.; Gutierrez, N.; Ellwood, S. R. et al. (2012): Comparative genomics to bridge Vicia faba with model and closely-related legume species: stability of QTLs for flowering and yield-related traits. In: TAG. Theoretical and applied genetics. Theoretische und angewandte Genetik 125 (8), pp. 1767-1782. DOI: 10.1007/s00122-012-1952-1.

Duc, G. (1997): Faba bean (Vicia faba L.). In: Field Crops Research 53 (1-3), pp. 99-109. DOI: 10.1016/S0378-4290(97)00025-7.

Duc, G.; Sixdenier, G.; Lila, M.; Furstoss, V. (1989): Search of genetic variability for vicine and convicine content in Vicia faba L.: a first report of a gene which codes for nearly zero-vicine and zeroconvicine contents. In:. 1. International Workshop on 'Antinutritional Factors (ANF) in Legume Seeds', Wageningen (Netherlands), 23-25 Nov 1988: Pudoc.

Frauen, M.; Röbbelen, G.; Ebmeyer, E. (1984): Quantitative Measurement of Quality Determining Constituents in Seeds of Different Inbred Lines from a World Collection of Vicia Faba. In: Hebblethwaite, Dawkins et al. (Hg.) -Vicia faba: Agronomy, p. 279-285.

Gallo, V.; Skorokhod, O. A.; Simula, L. F.; Marrocco, T.; Tambini, E.; Schwarzer, E. et al. (2018): No red blood cell damage and no hemolysis in G6PD-deficient subjects after ingestion of low vicine/convicine Vicia faba seeds. In: Blood 131 (14), pp. 1621-1625. DOI: 10.1182/blood-2017-09806364.

Gasim, S.; Link, W. (2007): Agronomic performance and the effect of self-fertilization on German winter faba beans. Journal of Central European Agriculture 8 (1), pp. 121-128.

Gauttam, V.; Kalia A.N. (2013): High performance thin layer chromatography method for simultaneous estimation of vicine, trigonelline and withaferin-a in a polyherbal antidiabetic formulation. In: International Journal of Pharmacy and Pharmaceutical Sciences 5 (2), pp. 367-371.

Goyoaga, C.; Burbano, C.; Cuadrado, C.; Varela, A.; Guillamón, E.; Pedrosa, M. M.; Muzquiz, M. (2008): Content and distribution of vicine, convicine and I-DOPA during germination and seedling growth of two Vicia faba L. varieties. In: Eur Food Res Technol 227 (5), pp. 1537-1542. DOI: 10.1007/s00217-008-0876-0.

Guillaume, J.; Bellec, R. (1977): Use of field beans (Vicia faba L) in diets for laying hens. In: British Poultry Science 18 (5), pp. 573-583. DOI: 10.1080/00071667708416406.

Gutiérrez, N.; Bakro, F.; Fernández-Romero, M. D.; Atienza, S.G.; Avila, C.M.; Duc, G.; INRA team, Torres, A. M. (2016): Strategies and advances to identify candidate genes for low vicine and convicine content in faba bean. Poster at Second International Legume Society Conference.

http://hdl.handle.net/10261/159702. See at https://digital.csic.es/handle/10261/159702, last checked on 17.02.2021.

Halle, I. (2006): 4. Antinutritive Pflanzeninhaltsstoffe sowie Pflanzenteile und Pflanzen mit antinutritiven Substanzen : 4.5 Vicin - Convicin. See online at https://literatur.thuenen.de/digbib_extern/bitv/zi040855.pdf, last checked on 17.02.2021

Khamassi, K.; Ben Jeddi, F.; Hobbs, D.; Irigoyen, J.; Stoddard, F.; O'Sullivan, D. M.; Jones, H. (2013): A baseline study of vicine-convicine levels in faba bean (Vicia faba L.) germplasm. In: Plant Genet. Resour. 11 (3), pp. 250-257. DOI: 10.1017/S1479262113000105. 
bioRxiv preprint doi: https://doi.org/10.1101/2021.02.19.431996; this version posted February 20, 2021. The copyright holder for this preprint (which was not certified by peer review) is the author/funder, who has granted bioRxiv a license to display the preprint in perpetuity. It is made available under aCC-BY-NC 4.0 International license.

Khazaei, H.; O’Sullivan, D.I M.; Jones, H.; Pitts, N.; Sillanpää, M. J.; Pärssinen, P. et al. (2015): Flanking SNP markers for vicine-convicine concentration in faba bean (Vicia faba L.). In: Mol Breeding 35 (1), pp. 1-6. DOI: 10.1007/s11032-015-0214-8.

Khazaei, H.; Purves, R. W.; Song, M.; Stonehouse, R.; Bett, K. E.; Stoddard, F. L.; Vandenberg, A. (2017): Development and validation of a robust, breeder-friendly molecular marker for the vc - locus in faba bean. In: Mol Breeding 37 (11). DOI: 10.1007/s11032-017-0742-5.

Khazaei, H.; Subedi, M.; Nickerson, M.; Martínez-Villaluenga, C.; Frias, J.; Vandenberg, A. (2019): Seed Protein of Lentils: Current Status, Progress, and Food Applications. In: Foods (Basel, Switzerland) 8 (9). DOI: 10.3390/foods8090391.

Köpke, U.; Nemecek, T. (2010): Ecological services of faba bean. In: Field Crops Research 115 (3), pp. 217-233. DOI: 10.1016/j.fcr.2009.10.012.

Kosambi, D.D. (1943): The estimation of map distances from recombination values. In: Annals of human genetics 12 (1), pp. 172-175. DOI: 10.1111/j.1469-1809.1943.tb02321.x.

Kulak, M.; Graves, A.; Chatterton, J. (2013): Reducing greenhouse gas emissions with urban agriculture: A Life Cycle Assessment perspective. In: Landscape and Urban Planning 111, pp. 68-78. DOI: 10.1016/j.landurbplan.2012.11.007.

Larbier, M. and Leclercq, B. (1994): Nutrition and Feeding of Poultry. In: Nottingham University Press, Sutton Bonington Campus, Loughborough.

Link, W.; Stelling, D.; Ebmeyer, E. (1994): Factors determining the performance of synthetics in Vicia faba L. 1. Heterogeneity, heterozygosity, and degree of cross-fertilization. In: Euphytica 75 (1-2), pp. 77-84. DOI: 10.1007/BF00024534.

LIS - Legume Information System, https://legumeinfo.org, more specifically https://legumeinfo.org/organism/Medicago/truncatula; last checked on 17.02.2021.

Luzzatto, L.; Arese, P. (2018): Favism and Glucose-6-Phosphate Dehydrogenase Deficiency. In: The New England journal of medicine 378 (1), pp. 60-71. DOI: 10.1056/nejmra1708111.

Marquardt R.R.; Campbell L.D.; Guenter W. (1981): Purification and identification of an egg size and fertility depressing factor (vicine) in faba beans [Vicia faba]. In: FABIS Newsletter.

Muduuli, D. S.; Marquardt, R. R.; Guenter, W. (1982): Effect of dietary vicine and vitamin E supplementation on the productive performance of growing and laying chickens. In: British Journal Of Nutrition 47 (1), pp. 53-60. DOI: 10.1079/BJN19820008.

Munduuli, D. S.; Marquardt, R. R.; Guenter, W. (1981): Effect of dietary vicine on the productive performance of laying chickens. In: Can. J. Anim. Sci. 61 (3), pp. 757-764. DOI: 10.4141/cjas81-091.

Naber, E. C.; Vogt, H.; Harnish, S.; Krieg, R.; Ueberschaer, K. H.; Rauch, H. W. (1988): Reproductive performance of hens fed field beans and potential relationships to vicine metabolism. In: Poultry science 67 (3), pp. 455-462. DOI: 10.3382/ps.0670455.

NIAB (2021). See online at https://www.niab.com/welcome-niab, last update on 03.01.2021, last checked on 03.01.2021.

Olaboro, G.; Marquardt, R. R.; Campbell, L. D.; Fröhlich, A. A. (1981a): Purification, Identification, and quantification of an Egg-weight-depressing factor (vicine) in fababeans (Vicia faba L.). In: J. Sci. Food Agric. 32 (12), pp. 1163-1171. DOI: 10.1002/jsfa.2740321205. 
bioRxiv preprint doi: https://doi.org/10.1101/2021.02.19.431996; this version posted February 20, 2021. The copyright holder for this preprint (which was not certified by peer review) is the author/funder, who has granted bioRxiv a license to display the preprint in perpetuity. It is made available under aCC-BY-NC 4.0 International license.

Olaboro, G.; Marquardt, R. R.; Campbell, L. D. (1981b): Isolation of the egg weight depressing factor in fababeans (Vicia faba L. var. minor). In: J. Sci. Food Agric. 32 (11), pp 1074-1080. DOI: 10.1002/jsfa.2740321106.

O'Sullivan, D. M.; Angra, D. (2016): Advances in Faba Bean Genetics and Genomics. In: Frontiers in genetics 7, p. 150. DOI: 10.3389/fgene.2016.00150.

Rispail, N.; Kaló, P.; Kiss, G. B.; Ellis, T. N. H.; Gallardo, K.; Thompson, R. D. et al. (2010): Model legumes contribute to faba bean breeding. In: Field Crops Research 115 (3), pp. 253-269. DOI: 10.1016/j.fcr.2009.03.014.

Santos J. R. P.; Ndeve A.D.; Huynh B.-L.; Matthews W. C.; Roberts P.A. (2018): QTL mapping and transcriptome analysis of cowpea reveals candidate genes for root-knot nematode resistance. PLOS ONE 13(1): e0189185. https://doi.org/10.1371/journal.pone.0189185.

Sirks, M. J. (1931): Beiträge zu einer genotypischen Analyse der Ackerbohne (Vicia faba L.). In: Genetica (13), pp. 210-631.

Sixdenier, G.; Cassecuelle, F.; Guillaumin, L.; Duc, G. (1996): Rapid spectrophotometric method for reduction of vicine and convicine in faba bean seed. In: Faba Bean Information Service.

Song, M. (2017): Preventing Favism by Selecting Faba Bean Mutants Using Molecular Markers. In: STEM Fellowship Journal 3 (1), pp. 2-6. DOI: 10.17975/sfj-2017-001.

Statistisches Bundesamt (2020): Ackerland nach Hauptfruchtgruppen und Fruchtarten. See online at https://www.destatis.de/DE/Themen/Branchen-Unternehmen/Landwirtschaft-ForstwirtschaftFischerei/Feldfruechte-Gruenland/Tabellen/ackerland-hauptfruchtgruppen-fruchtarten.html, last update on 03.08.2020, last checked on 27.09.2020.

Roth, A.; Ding, J.; Morin, R.; Crisan, A.; Ha, G.; Giuliany, R.; Bashashati, A.; Hirst, M.; Turashvili, G.; Oloumi, A.; Marra, M. A.; Aparicio, S.; Shah, S. P. (2012): JointSNVMix: a probabilistic model for accurate detection of somatic mutations in normal/tumour paired next-generation sequencing data. Bioinformatics 1;28(7), pp. 907-13. DOI: 10.1093/bioinformatics/bts053.

Tacke, R.; Angra, D.; O'Sullivan, D.; Link, W. (2018): High-resolution map fragment of the genomic vicinity of the VC-locus, harbouring a major allele for very low vicine and convicine seed content in seeds of faba bean (Vicia faba L.). Poster at GPBC2018 German Plant Breeding Conference Gaterlseben(Wernigerode); See online at https://www.uni-goettingen.de/de/566949.html, last checked on 17.02.2021.

Taylor, J.; Butler, D. (2017): R Package ASMap: Efficient Genetic Linkage Map Construction and Diagnosis. In: J. Stat. Soft. 79 (6), pp. 1-29. DOI: 10.18637/jss.v079.i06.

Varshey, R.K.; Song, C.; Saxena, R.K.;...; Wang, J.; Cook, D.R. (2013): Draft genome sequence of chickpea (Cicer arietinum) provides a resource for trait improvement. Nature Biotechnology 31, pp. 240246.

Webb, A.; Cottage, A.; Wood, T.; Khamassi, K.; Hobbs, D.; Gostkiewicz, K.; White, M.; Khazaei, H.; Ali, M.; Street, D.; Duc, F.; Stoddard, F.L.; Maalouf, F.; Ogbonnaya, F. C.; Link, W.; Thomas, J.; Sullivan, D.M. (2016): A SNP-based consensus genetic map for synteny-based trait targeting in faba bean ( $V i-$ cia faba L.). Plant Biotechnology Journal 14 (1), pp. 177-185. DOI: 10.1111/pbi.12371. 